\title{
Mycoparasitic capabilities of diverse native strain of Trichoderma spp. against Fusarium oxysporum f. sp. lycopersici
}

\author{
Lakshman Prasad ${ }^{1}$, Sorabh Chaudhary ${ }^{2 *}$, Sushma Sagar ${ }^{2}$ and Akash Tomar ${ }^{3}$ \\ ${ }^{1}$ Senior Scientist, Division of Plant Pathology, IARI Pusa Campus, New Dehli, INDIA \\ ${ }^{2}$ Department of Agriculture Biotechnology, S.V. Patel University of Agriculture and Technology, Meerut-250 110, INDIA \\ ${ }^{3}$ Department of Recombination Technology, Collage of Biotechnology, S.V. Patel University of Agriculture and \\ Technology, Meerut-250 110, INDIA \\ *Corresponding author. E-mail: sorabh.gene@gmail.com
}

Received: August 15, 2015; Revised received: February 6, 2016; Accepted: May 13, 2016

\begin{abstract}
The Fusarium wilt of tomato (Lycopersicon esculentum Mill.) caused by Fusarium oxysporum f. sp. lycopersici (Sacc.) Snyder and Hansen is recognised as one of the most devastating disease and major yield limiting factor in tomato growing regions worldwide. For eco-friendly and sustainable management of the disease, 19 Trichoderma native isolates belonging to 3 species of the genus, $T$. harzianum, $T$. asperellum and $T$. virens were evaluated in vitro against the pathogen using dual culture method. Out of 19 isolates, 8 isolates showed mycoparasitism, 8 isolates showed antibiosis and remaining showed lysis. Microscopic observations of Fusarium oxysporum f. sp. lycopersici (FOL) growth in dual cultures revealed that growth inhibition occurred just before near to contact with the antagonist. All T. harzianum isolates tested exhibited coiling around the hyphae of FOL. Isolates of $T$. harzianum, showed good coiling and growth inhibition of the pathogen. The $T$. harzianum strains did not differ in coiling pattern and gave somewhat equal coiling performances. Strains of $T$. asperellum, showed coiling but the coiling pattern of all these strains was different. Only one strain of $T$. virens showed coiling out of 2 strains. Among them $T$. harzianum (SVPUTh91) showed the best performance in vitro as biological control agent against FOL followed by $T$. asperellum and $T$. virens, resulting in 83,73 and $65 \%$ reduction in colony growth, respectively.
\end{abstract}

Keywords: Antibiosis, Coiling, Fusarium, Lysis, Trichoderma

\section{INTRODUCTION}

Tomato (Solanum lycopersicum L.) is the world's largest vegetable crop after potato and sweet potato, grown in all parts of India. Its popularity is due to its high nutritive value, diversified use, and nutritional significance as a source of vitamins A, C potassium, minerals and fibers (Sundaramoorthy and Balabaskar, 2013). It occupies number one position in its nutrient contribution to human diet. India ranks second in the area as well as in production of tomato, and share $7.6 \%$ of the world total production, at present the estimated area under cultivation and production is 8.82 lakh ha and 187.4 lakh tonnes, respectively (NHB Database, 2014). Tomato is affected by various biotic diseases, causing negatively effect on plant growth and the produced yield.

Fungal phytopathogens pose serious problems worldwide in the cultivation of economically important plants, especially in the subtropical and tropical regions (Brimner and Boland, 2003). Out of these, pathogenic fungi especially, the wilt caused by species of Fusarium remain to be a challenging task in terms of management (Agrios, 2005; Srinon et al., 2006). At present, around $30 \%$ of all plant species are affected by pathogens that cause disease and death of individual plants. Wilt of tomato caused by Fusarium oxysporum f. sp. lycopersici (Sacc.) Snyder and Hansen is one of the most important diseases world-wide (Cal et al., 2004). Pesticides and organic compounds that are widely used to control plant pathogens do not degrade completely and leave toxic residues in food chain (Chet, 1987; Lynch, 1990). Their applications have an abuse as favoured the development of fungicidal resistant in pathogens. Another risk potential have been observed as the greater probability of decreasing the effect through genetic shifts in the population, whereas fungicides of broad spectrum produce adverse consequences on non-target organisms (Tjamos et al., 1992).

Biological control of plant disease is the suppression of disease symptoms and disease incidence by the application of a biological agent, usually a microorganism (Avis et al.,2001). Several fungal and bacterial biocontrol agents have been used for achieving plant disease control, amongst them Trichoderma group has been found effective against aerial, root and soil pathogens (Weller, 1988; Whipps et al., 1993; Elad et al., 1998 a, b; van Loon et al., 1998; Elad, 2000; Harman et al., 2004; Chaube et al., 2002). Trichoderma species have 
been increasingly used as biological control agents and a few of the isolates are commercially available (Henis, 1984; Chet and Baker, 1980; Chet and Inbar, 1994). Results from different studies showed that several strains of Trichoderma exerted significant reducing effects on plant diseases caused by pathogens such as R. solani, S. rolfsii, Pythium aphanidermatium, Fusarium oxysporum, F. culmorum, Collectotrichum falcatum and Gaeumannomyces graminis under greenhouse and field conditions (Sivan and Chet, 1993; Inbar et al., 1994; Chet and Baker, 1981; Prasad et al., 2010). Isolates of Trichoderma spp. can produce lytic enzymes (Haran et al., 1996), and antifungal antibiotics (Dennis and Webster, 1971a; Brewer et al., 1987; Almassi et al., 1991), which inhibit the growth of pathogenic fungi. However, it is reported that all the isolates of Trichoderma spp. are not equally effective in control of pathogen in vitro and in vivo conditions to control diseases (Biswas and Das, 1999; Ramezani, 2008). Therefore, specific isolates of Trichoderma spp. are needed for successful control of a particular pathogen. The present study on the efficacy of the mycelial growth inhibition of $F$. oxysporum f. sp. lycopersici by Trichoderma spp. and investigating the mechanisms involved in inhibition under microscopic observation that could be used in the future for $F$. oxysporum control.

\section{MATERIALS AND METHODS}

Collection of samples: Soil samples were collected from different geographical areas of Western region of India. Soil samples (50 g each) were collected at four corners and the centre of the different crop fields from various places. The samples were collected from top 2$5 \mathrm{~cm}$ depth of rhizospheric soils. The soil samples were then transferred into sterile polyethylene bags and transported to the laboratory and kept at room temperature for further use.

Isolation and identification of Trichoderma spp.: One gm of the soil sample was taken and added to $1 \mathrm{ml}$ of sterilized distilled water to make a dilution of $10^{-1}$. The soil suspension was left during $5 \mathrm{~min}$. at ambient temperature to release conidia and hyphae adhering to soil particles. This suspension was then subjected to serial dilutions and a dilution of $10^{-5}$ was attained. One $\mathrm{ml}$ of each dilution viz., $10^{-3}$ to $10^{-4}$ was poured on to potato dextrose agar (PDA) medium supplemented with $500 \mathrm{mg} / \mathrm{l}$ of antibiotic Chloramephenicol. The plates were then incubated at $27 \pm 2^{\circ} \mathrm{C}$ for one week. The distinct colonies were picked and transferred in to PDA containing petriplates at least two times to obtain pure cultures using single spore culture. These isolates were identified on the basis of their morphological (Rifai, 1969) and molecular characterization (Prasad et al., 2012) using ITS1 and ITS4 markers (White et al., 1990). Cultures were identified according to conidiophore, shape of the phialides and emergence of phialophores and phialospores. The purified and identified cultures of Trichoderma spp. were maintained on Potato Dextrose Agar (PDA) medium and stored at $4^{\circ} \mathrm{C}$ for further use and sub cultured every two months intervals. For long terms storage strains were conserved in $50 \%$ glycerol at $-80^{\circ} \mathrm{C}$.

Plate confrontation assays: Variation in the antagonistic activity of 19 isolates belonging to $T$. harzianum, $T$. asperellum and $T$. virens were evaluated in vitro, soil-borne plant pathogen Fusarium oxysporum f. sp. lycopersici and the ability of Trichoderma spp. to coil around $F$. oxysporum in dual culture technique (Dennis and Webster, 1971). Dual culture was carried out by using one week-old culture of $F$. oxysporum and Trichoderma on PDA. The agar medium was inoculated with a $5 \mathrm{~mm}$ diameter disc of antagonist positioned diametrically opposite a $5 \mathrm{~mm}$ diameter disc of pathogen. The distance between discs was approx. $5 \mathrm{~cm}$. The plates were incubated at $27 \pm 2^{\circ} \mathrm{C}$ in BOD and measurements were taken after four days. In the control treatment, a sterile agar disc $(0.5 \mathrm{~mm}$ diam.) was placed instead of Trichoderma isolates. There were three replicates for each treatment. At the end of incubation period, redial growth was measured. Types of interactions in dual culture were studied seventh day after inoculation. After both the fungi came in contact with each other, the contact/inhibition zone mounted under lectophenol-cotton-blue over a clean glass slide and observations were made under optical microscope. The reduction in mycelial growth was recorded and the percentage of inhibition over control for each treatment was calculated in this dual plate culture test as given in Table 1. The efficacy of Trichoderma spp. in suppressing redial growth was calculated as follows:

$\%$ Reduction in growth $=(\mathrm{X}-\mathrm{Y}) /(\mathrm{X}) \times 100$

$\mathrm{X}=$ Growth of pathogen alone without antagonist (control)

$\mathrm{Y}=$ Growth of pathogen along with the antagonist

\section{RESULTS AND DISCUSSION}

Isolation and identification of Trichoderma isolates: A total of 24 isolates, in which 8 strains of $T$. harzianum, 9 strains of $T$. asperellum, 2 strains of $T$. virens, 2 strains of Hypocrea jecorina, 1 strain of $T$. hamatum, 1 strain of T. aureoviride and 1 strain of $H$. rufa isolated from various soil samples which were collected from different places and crops like- potato, tomato and cabbage. The rDNA-ITS-PCR amplified nucleotide sequences of these Trichoderma isolates have been deposited in the GenBank database under accession numbers KC 312632.1 to KC 312652.1 (Table 1). Colony morphology of all the isolates was more or less similar showing sparse to thin colony mycelial mass with whitish border in some cases. Sporulation started after $48 \mathrm{~h}$ of incubation at $27 \pm 2^{\circ} \mathrm{C}$ for all the isolates. Out of 24 isolates, 11 produced dark green colour colonies, eight yellowish green and the remaining five light green. Eight isolates produced defuse mycelial growth, while the rest were of cottony 
white type. Reverse side colour was yellow green in 10 isolates, light drab in 4 and no pigmentation was found in 10 isolates (Table 2). The same findings like pale or yellowish colour of reverse of colonies, rapid growth of Trichoderma isolates were recorded by several workers (Samuels et al., 2002; Sharma and Singh, 2014). Morphological characterization was conventionally used in the identification of Trichoderma sp., and it remains as a potential method to identify Trichoderma sp. (Gams and Bissett, 2002; Anees et al., 2010).

In vitro antagonism test: In the present study 19 out of 24 Trichoderma spp., isolated from different geographical region were selected for screening against fungal pathogens Fusarium oxysporum f. sp. lycopersici.

Mycelial growth inhibition of $F$. oxysporum f. sp. Lycopersici: Differential action of the biocontrol agents was noticed on mycelial growth of the $F$. oxysporum. A reduction in the growth of $F$. oxysporum was evidenced when it was paired with antagonists. Among all the treatments, fast mycelial growth (7.5 $\mathrm{cm}$ ) was recorded from the isolate- SVPUTh91 of $T$. harzianum followed by isolate SVPUTh10 $(7.3 \mathrm{~cm})$, SVPUTh38 $(7 \mathrm{~cm})$, SVPUTh47, SVPUTh36 $(6.9 \mathrm{~cm})$ and SVPUTh82, SVPUTh94, SVPUTh98 $(6.7 \mathrm{~cm})$ (Fig. 1). The results indicate that among the nineteen species of Trichoderma tested for their in vitro antagonism, the T. harzianum (SVPUTh91 and SVPUTh10) was consistently found to be the most effective with $83 \%$ and $82 \%$, respectively, reduction in radial growth of pathogen over control and was significantly superior to all other isolates. T. harzianum (SVPUTh38) is the next best and it reduced the growth of pathogen to $80 \%$ followed by $T$. harzianum (SVPUTh54 and SVPUTh74). T. asperellum isolates (SVPUAsp47, SVPUAsp58) showed $70 \%$ reduction in mycelial growth of pathogen. T. virens (SVPUTv56 and SVPUTv82) was the least effective with $65 \%$ reduction to the test pathogen (Table 3 ). The present finding was supported by several workers (Choudary et al., 2007; Ramezani, 2010). Joshi et al., (2010) found the antagonistic variability in different isolates of Trichoderma spp. collected from different places of India. Siameto et al., (2011) also revealed that sixteen isolates of T. harzianum collected from different lands were found highly antagonist against five test fungus (Rhizoctonia solani, Pythium spp., Fusarium graminearum, F. oxysporum f. sp. phaseoli and F. oxysporum f. sp. lycopersici).

Mycoparasitism assays: A second mechanism of pathogen control was mycoparasitism. In dual cultures of $F$. oxysporum and the antagonists several morphological changes were seen when inhibition zone were analyzed under optical microscope. Microscopic observation of the interaction region between $F$. oxysporum with $T$. harzianum showed that $T$. harzianum hyphae coiled around those of $F$. oxysporum. Lysis of hyphae of $F$. oxysporum with close contact of $T$. harzianum hyphae was observed. Penetration of Trichoderma hyphae of strain SVPUTh91 was observed in this study (Fig. 2). All the observations were compared

Table 1. Morphological and Molecular Identified isolates of Trichoderma spp. used in this study.

\begin{tabular}{|c|c|c|c|c|c|}
\hline Strain & Crop & $\begin{array}{l}\text { Morphological } \\
\text { identification }^{\mathrm{a}} \\
\end{array}$ & $\begin{array}{l}\text { Genbank accession no. } \\
\text { (ITS Sequence) }\end{array}$ & $\begin{array}{l}\text { Molecular } \\
\text { identification }\end{array}$ & $\begin{array}{l}\text { Definitive iden- } \\
\text { tification }\end{array}$ \\
\hline SVPUTh10 & POTATO & H. lixii & KC 312632 & H. lixii & H. lixii \\
\hline SVPUTh38 & POTATO & H. lixii & KC 312633 & H. lixii & H. lixii \\
\hline SVPUTh50 & POTATO & T. harzianum & KC 312634 & T. harzianum & T. harzianum \\
\hline SVPUTh94 & POTATO & H. lixii & KC 312639 & H. lixii & H. lixii \\
\hline SVPUTh77 & POTATO & H. lixii & KC 312640 & H. lixii & H. lixii \\
\hline SVPUTh91 & POTATO & H. lixii & KC 312644 & H. lixii & H. lixii \\
\hline SVPUTh96 & POTATO & H. lixii & KC 312645 & H. lixii & H. lixii \\
\hline SVPUTh98 & POTATO & H. lixii & KC 312646 & H. lixii & H. lixii \\
\hline SVPUAsp47 & POTATO & T. asperellum & KC 312631 & T. asperellum & T. asperellum \\
\hline SVPUAsp32 & POTATO & T. asperellum & KC 312635 & T. asperellum & T. asperellum \\
\hline SVPUAsp51 & POTATO & T. asperellum & KC 312638 & T. asperellum & T. asperellum \\
\hline SVPUAsp55 & POTATO & T. asperellum & KC 312641 & T. asperellum & T. asperellum \\
\hline SVPUAsp58 & POTATO & T. asperellum & KC 312643 & T. asperellum & T. asperellum \\
\hline SVPUAsp82 & POTATO & T. asperellum & KC 312647 & T. asperellum & T. asperellum \\
\hline SVPUAsp93 & POTATO & T. asperellum & KC 312649 & T. asperellum & T. asperellum \\
\hline SVPUAsp94 & TOMATO & T. asperellum & KC 312650 & T. asperellum & T. asperellum \\
\hline SVPUAsp99 & POTATO & T. hamatum & KC 312636 & T. hamatum & T. hamatum \\
\hline SVPUAur57 & POTATO & T. aureoviride & KC 312637 & T. aureoviride & T. aureoviride \\
\hline SVPUJec45 & POTATO & NI & KC 312642 & H. jecorina & H. jecorina \\
\hline SVPUJec27 & POTATO & NI & KC 312651 & H. jecorina & H. jecorina \\
\hline SVPUHam54 & POTATO & T. hamatum & KC 312636 & T. hamatum & T. hamatum \\
\hline SVPUTv56 & POTATO & H. virens & KC 312648 & H. virens & H. virens \\
\hline SVPUTV82 & CABBAGE & H. virens & KC 312653 & H. virens & H. virens \\
\hline SVPUTr22 & CABBAGE & NI & KC 312652 & H. rufa & H. rufa \\
\hline
\end{tabular}


Table 2. Colony diameter and morphological characteristics of Trichoderma isolates.

\begin{tabular}{|c|c|c|c|c|}
\hline \multirow{2}{*}{$\begin{array}{l}\text { Trichoderma } \\
\text { isolates }\end{array}$} & \multirow{2}{*}{$\begin{array}{l}\text { Diameter } \\
(\mathrm{cm}) \text { at } 96 \mathrm{~h}\end{array}$} & \multicolumn{3}{|c|}{ Morphological characteristics of Trichoderma isolates at various duration } \\
\hline & & After 36 h & After $60 \mathrm{~h}$ & After 90 h \\
\hline $\begin{array}{l}\text { SVPUTh38 } \\
\text { SVPUTh50 }\end{array}$ & 4.5 & $\begin{array}{l}\text { Normal off white } \\
\text { growth appears in- } \\
\text { oculum, very thin } \\
\text { mycelium surround } \\
\text { the inoculum }\end{array}$ & $\begin{array}{l}\text { Compact fluffy light green } \\
\text { sporulation on older re- } \\
\text { gion }\end{array}$ & $\begin{array}{l}\text { Light green away from inoculums } \\
\text { inner circle sparse and outer } \\
\text { circle with dense growth, encircled } \\
\text { dense with fluffy mycelium }\end{array}$ \\
\hline $\begin{array}{l}\text { SVPUAsp47 } \\
\text { SVPUAsp58 } \\
\text { SVPUTr22 }\end{array}$ & 3.0 & $\begin{array}{l}\text { Normal trasulant } \\
\text { white defused } \\
\text { mycelial growth on } \\
\text { inoculums }\end{array}$ & $\begin{array}{l}\text { Around inoculum light } \\
\text { yellow green mycelium } \\
\text { growth after dark green } \\
\text { sporulation }\end{array}$ & $\begin{array}{l}\text { On inoculum yellow growth } \\
\text { surrounded by dirty green growth } 2 \\
\text { cm encircled by dark green mycelium }\end{array}$ \\
\hline $\begin{array}{l}\text { SVPUAur57 } \\
\text { SVPUHam54 }\end{array}$ & 3.7 & $\begin{array}{l}\text { Cottony off white } \\
\text { mycelial growth on } \\
\text { inoculums }\end{array}$ & $\begin{array}{l}\text { Around the inoculums } \\
\text { very light green fluffy } \\
\text { mycelium encircled by } 2 \\
\text { cm dense light green } \\
\text { sporulation }\end{array}$ & $\begin{array}{l}\text { Around inoculum } 5 \mathrm{~cm} \text { dia white } \\
\text { mycelial growth surrounded by whit- } \\
\text { ish green mycelium } 2 \mathrm{~cm} \text { dia }\end{array}$ \\
\hline $\begin{array}{l}\text { SVPUAsp51 } \\
\text { SVPUAsp55 }\end{array}$ & 4.5 & $\begin{array}{l}\text { Cottony white } \\
\text { mycelial growth on } \\
\text { the inoculums }\end{array}$ & $\begin{array}{l}\text { Around inoculums dark } \\
\text { green mycelium } \\
\text { encircled by } 2 \mathrm{~cm} \text { light } \\
\text { green sporulation }\end{array}$ & $\begin{array}{l}\text { Around inoculums } 3 \mathrm{~cm} \text { dia dark } \\
\text { green after } 4 \mathrm{~cm} \text { dia dense fluffy off } \\
\text { white mycelium then dark green }\end{array}$ \\
\hline $\begin{array}{l}\text { SVPUAsp82 } \\
\text { SVPUAsp93 } \\
\text { SVPUAsp32 }\end{array}$ & 3.4 & $\begin{array}{l}\text { Cottony white } \\
\text { mycelial growth on } \\
\text { the inoculum sparse } \\
\text { very thin mycelium }\end{array}$ & $\begin{array}{l}\text { Sparse } 4 \mathrm{~cm} \text { mycelium } \\
\text { growth, media become } \\
\text { yellow around inoculum } \\
\text { encircled with compact } \\
\text { dark green sporulation }\end{array}$ & $\begin{array}{l}\text { Around inoculums } 5 \mathrm{~cm} \text { dia white } \\
\text { mycelial growth } \\
\text { surrounded by sparse whitish green } \\
\text { mycelium } 1.5 \mathrm{~cm} \text { encircled by dark } \\
\text { green } 0.5 \mathrm{~cm} \text { dia. }\end{array}$ \\
\hline $\begin{array}{l}\text { SVPUTv56 } \\
\text { SVPUTv82 }\end{array}$ & 3.9 & $\begin{array}{l}\text { Cottony white } \\
\text { mycelial growth on } \\
\text { the inoculums }\end{array}$ & $\begin{array}{l}\text { On the inoculum white } \\
\text { mycelial growth light } \\
\text { fluffy green sporulation } 4 \\
\mathrm{~cm}\end{array}$ & $\begin{array}{l}\text { Around inoculum } 4 \mathrm{~cm} \text { dia white } \\
\text { mycelium growth surrounded by light } \\
\text { green bands encircled by off white } \\
\text { mycelium }\end{array}$ \\
\hline $\begin{array}{l}\text { SVPUJec27 } \\
\text { SVPUJec45 }\end{array}$ & 4.3 & $\begin{array}{l}\text { Off white mycelial } \\
\text { growth on the } \\
\text { inoculum very thin } \\
\text { mycelium surround } \\
\text { the inoculums }\end{array}$ & $\begin{array}{l}\text { White mycelium on inocu- } \\
\text { lums } 2.7 \mathrm{~cm} \text { after raised } \\
\text { cottony off white growth } \\
8.7 \mathrm{~cm}\end{array}$ & $\begin{array}{l}\text { Inoculum covered with snow white } \\
\text { mycelium surrounded sparse growth } \\
\text { later thick dirty green slightly fluffy } \\
\text { raised } 1.5 \mathrm{~cm} \text { then light green }\end{array}$ \\
\hline $\begin{array}{l}\text { SVPUTh10 } \\
\text { SVPUTh91 } \\
\text { SVPUTh94 }\end{array}$ & 5.2 & $\begin{array}{l}\text { Normal watery trasu- } \\
\text { lant off white defused } \\
\text { mycelial growth } \\
\text { around the inoculums }\end{array}$ & $\begin{array}{l}\text { Off White mycelium on } \\
\text { inoculums } 2 \mathrm{~cm} \text { after } \\
\text { raised cottony light green } \\
\text { growth } 6.7 \mathrm{~cm}\end{array}$ & $\begin{array}{l}\text { Inoculum covered with snow white } \\
\text { mycelium surrounded sparse growth } \\
\text { light green slightly fluffy raised } 2.5 \\
\mathrm{~cm} \text { then light green }\end{array}$ \\
\hline $\begin{array}{l}\text { SVPUAsp94 } \\
\text { SVPUAsp99 }\end{array}$ & 3.2 & $\begin{array}{l}\text { Sparse whitish thick } \\
\text { growth }\end{array}$ & $\begin{array}{l}\text { On inoculums white } \\
\text { growth dense light sparse } \\
\text { fluffy green sporulation } \\
4.5 \mathrm{~cm} \\
\text { media becomes yellow } \\
\text { around inoculums }\end{array}$ & $\begin{array}{l}\text { Inoculum covered with yellow } \\
\text { growth surrounded dirty green } \\
\text { growth } 2 \mathrm{~cm} \text {, encircled with slightly } \\
\text { raised growth }\end{array}$ \\
\hline $\begin{array}{l}\text { SVPUTh77 } \\
\text { SVPUTh96 } \\
\text { SVPUTh98 }\end{array}$ & 4.0 & $\begin{array}{l}\text { Yellow growth on } \\
\text { inoculums } \\
\text { surrounds sparse } \\
\text { cottony white growth }\end{array}$ & $\begin{array}{l}\text { Yellow growth on the } \\
\text { inoculums sparse light } \\
\text { green sporulation } \\
\text { appears white dense } \\
\text { growth at periphery media } \\
\text { becomes yellow }\end{array}$ & $\begin{array}{l}\text { Inoculums covered with pale yellow } \\
\text { or dark brown growth surrounded } \\
\text { dirty green growth } 2.5 \mathrm{~cm} \text { encircled } \\
\text { with slightly raised growth }\end{array}$ \\
\hline
\end{tabular}

with the control plate study of $F$. oxysporum. All isolates of $T$. harzinum showed antibiosis and lysis mechanism of parasitism. The least growth inhibition efficacy showed by $T$. virens isolates. The in vitro culture of $F$. oxysporum and $T$. harzianum together led to a variety of interactions. $F$. oxysporum growth was generally inhibited, the hyphae lysed on dual culture media and hyphae were intensely parasitized by $T$. harzianum. Highest rapid growth $(7.5$ and $7.3 \mathrm{~cm})$ of the antagonist isolate of $T$. harzianum (SVPUTh91 and SVPUTh10, respectively) compared with slow growth of the $F$. oxysporum isolate $(1.5 \mathrm{~cm})$ and showed the high growth inhibition efficiency 83 and $82 \%$ respectively, showed the lysis of the Fusarium mycelium, could have been caused by nutrient depletion, and therefore mycelial growth inhibition. The inhibition could also be caused by production of toxic substances like enzymes, metabolites, antibiotics, volatile and non -volatile substances, released by the antagonist, as has been shown in other studies with phytopathogenic fungi (Askew and Laing, 1994; Kay and Steward, 1994). The pathogen mycelia then disintegrated suggesting enzyme action. Metcalf and Wilson (2001) demonstrated possible role of chitinolytic and/or glucanases 


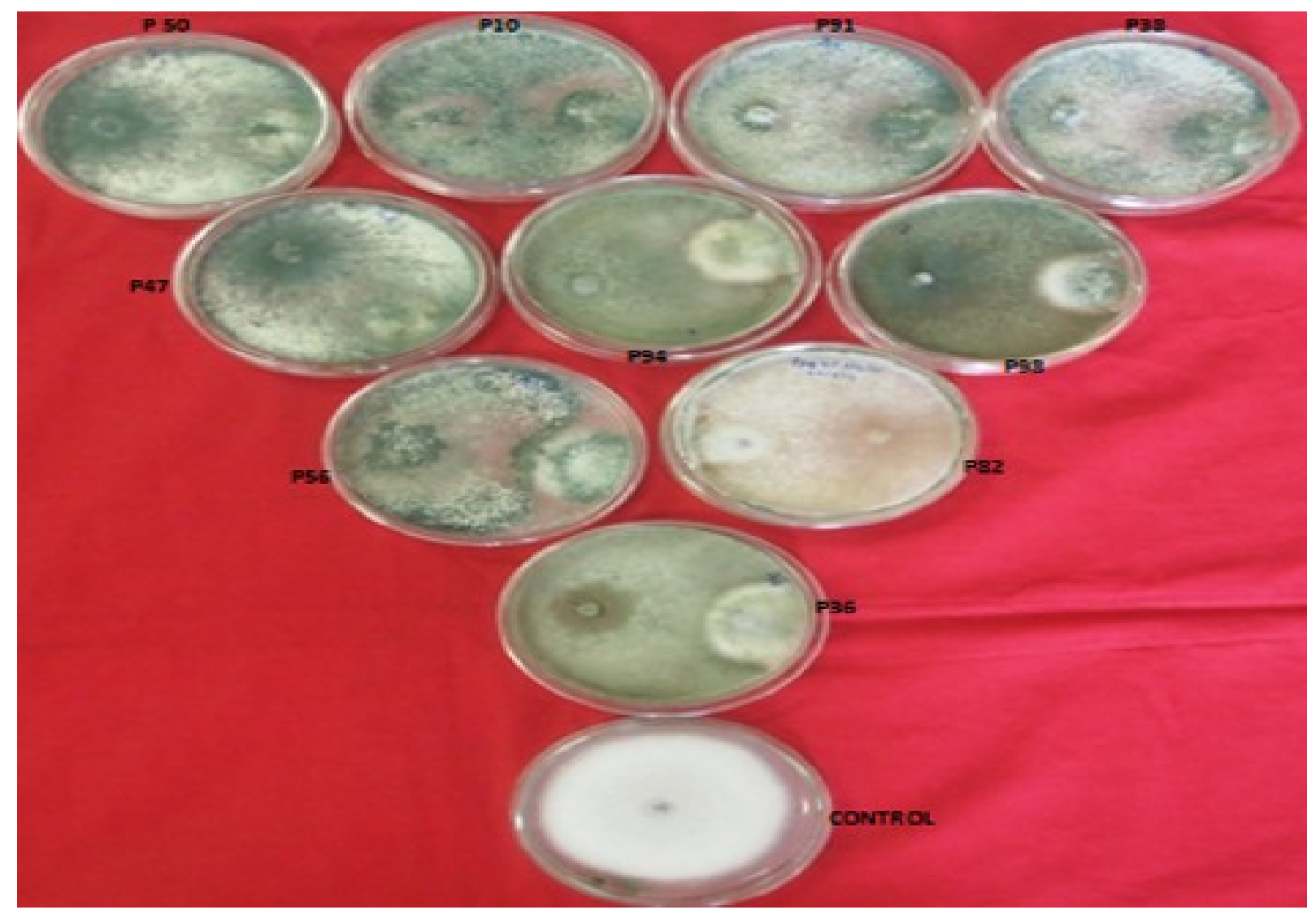

Fig. 1. Antagonism between Trichoderma isolates and Fusarium oxysporum $f$. sp. lycopersici at 7 Days after inoculation. Each Petridishes containing Fusarium oxysporum (pathogen) at the right and Trichoderma spp. (antagonists) at the left side. Last Petriplate containing Fusarium colony only (control).
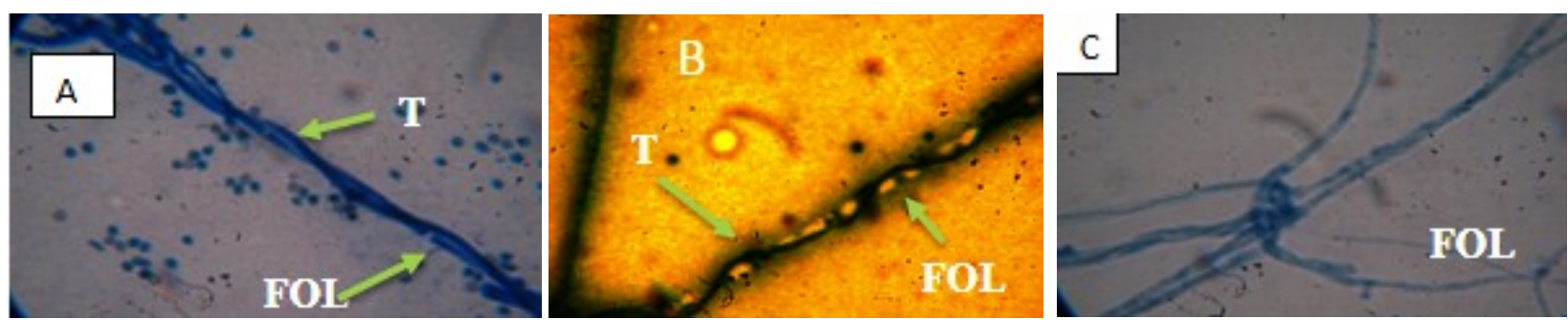

Fig. 2. Trichoderma harzianum undergoes with some mechanisms inhibiting the mycelial growth of Fusarium oxysporum. (A) T. harzianum (T) mycelium coiling around Fusarium oxysporum $f$. sp. lycopersici (FOL) mycelium, (B) Lysis of hyphae of Fusarium oxysporum, (C) Fusarium oxysporum mycelium (control culture).

enzymes in biocontrol by Trichoderma. Ojha and Chatterjee (2011) recorded T. harzianum to be the best in rank with $T$. viride and $T$. harzianum towards their antagonist activity against $F$. oxysporum and production of lytic enzymes, glucanase and chitinase. These enzymes function by breaking down the polysaccharides, chitin, and fungal cell wall, thereby destroying cell wall integrity limiting the growth of the pathogen (Siameto et al., 2011).

Antibiosis/ lysis was another mechanism used by Trichoderma to control pathogen. Inhibition by antibiotic have been documented by Claydon et al. (1987), Dubey and Suresh (2006), Kucuk and Kivanc (2003) and Lynch (1990). Claydon et al. (1987) reported inhibition due to antibiotics trichodermin, harzianum A and harzianolide. Dubey and Suresh (2006) reported that non-volatile substances produced by $T$. harzianum are inhibitory to $F$. oxysporum f. sp. ciceris causing chickpea wilt.

\section{Conclusion}

Biological control is a promising tool to maintain current level of agriculture production while reducing the release of polluting chemical pesticides to the environment.. In this study, the mycoparasitism inhibitory effects of 19 Trichoderma isolates belongs to three species (T. harzianum, T. virens and T. asperellum) on the growth of Fusarium oxysporum f. sp. lycopersici were investigated. The maximum and minimum inhibitory effect was caused by $T$. 
Table 3. Growth inhibition of Fusarium oxysporum f. sp. lycopersici in dual culture by different isolates of Trichoderma spp.

\begin{tabular}{|c|c|c|c|c|c|c|c|}
\hline \multirow{3}{*}{$\begin{array}{l}\text { Trichoderma } \\
\text { isolates }\end{array}$} & \multicolumn{6}{|c|}{ Growth inhibition efficiency of Trichoderma spp. in dual culture } & \multirow{3}{*}{$\begin{array}{l}\text { Type of } \\
\text { Inhibition }\end{array}$} \\
\hline & \multicolumn{2}{|c|}{$\begin{array}{l}5 \text { days after } \\
\text { inoculation }\end{array}$} & \multicolumn{2}{|c|}{$\begin{array}{l}6 \text { days after } \\
\text { inoculation }\end{array}$} & \multicolumn{2}{|c|}{$\begin{array}{l}7 \text { days after } \\
\text { inoculation }\end{array}$} & \\
\hline & $\begin{array}{l}\text { Linear } \\
\text { Growth } \\
(\mathrm{cm})\end{array}$ & $\begin{array}{l}\text { Growth } \\
\text { Inhibition } \\
(\%)\end{array}$ & $\begin{array}{l}\text { Linear } \\
\text { Growth } \\
(\mathrm{cm})\end{array}$ & $\begin{array}{l}\text { Growth } \\
\text { Inhibition } \\
(\%)\end{array}$ & $\begin{array}{l}\text { Linear } \\
\text { Growth } \\
\text { (cm) }\end{array}$ & $\begin{array}{l}\text { Growth } \\
\text { Inhibition } \\
(\%)\end{array}$ & \\
\hline SVPUTh38 & 2.33 & 43.5 & 2.00 & 70.0 & 1.76 & 80.4 & Antibiosis \\
\hline SVPUTh50 & 2.76 & 33.0 & 2.36 & 64.5 & 1.96 & 82.2 & Lysis \\
\hline SVPUTh54 & 2.26 & 45.1 & 2.03 & 69.5 & 1.80 & 80.0 & Antibiosis \\
\hline SVPUTh74 & 2.43 & 41.1 & 2.13 & 68.0 & 1.80 & 80.0 & Antibiosis \\
\hline SVPUTh91 & 2.66 & 35.5 & 2.43 & 63.5 & 1.60 & 83.5 & Lysis \\
\hline SVPUTh94 & 2.66 & 35.5 & 2.36 & 64.5 & 1.50 & 82.2 & Antibiosis \\
\hline SVPUTh10 & 2.63 & 36.2 & 2.33 & 65.0 & 1.56 & 82.6 & Lysis \\
\hline SVPUTh98 & 2.66 & 35.5 & 2.40 & 64.0 & 1.83 & 79.6 & Antibiosis \\
\hline SVPUAsp47 & 3.03 & 26.6 & 2.86 & 57.0 & 2.63 & 70.7 & Mycoparasitism \\
\hline SVPUAsp32 & 2.83 & 31.4 & 2.66 & 60.0 & 2.36 & 73.7 & Mycoparasitism \\
\hline SVPUAsp51 & 2.63 & 36.3 & 2.53 & 62.0 & 2.16 & 76.6 & Mycoparasitism \\
\hline SVPUAsp55 & 3.00 & 27.4 & 2.70 & 59.9 & 2.36 & 76.3 & Antibiosis \\
\hline SVPUAsp58 & 3.00 & 27.4 & 2.46 & 62.9 & 2.10 & 71.5 & Mycoparasitism \\
\hline SVPUAsp82 & 2.66 & 35.5 & 2.46 & 62.9 & 2.13 & 76.3 & Antibiosis \\
\hline SVPUAsp93 & 3.10 & 25.0 & 2.83 & 57.5 & 2.56 & 73.7 & Mycoparasitism \\
\hline SVPUAsp94 & 2.70 & 34.7 & 2.40 & 64.0 & 2.13 & 76.3 & Antibiosis \\
\hline SVPUAsp99 & 3.26 & 20.9 & 2.63 & 60.5 & 2.36 & 73.7 & Mycoparasitism \\
\hline SVPUTv56 & 3.66 & 11.2 & 3.50 & 47.5 & 3.13 & 65.0 & Mycoparasitism \\
\hline SVPUTv82 & 2.93 & 29.1 & 3.03 & 54.5 & 3.03 & 66.3 & Mycoparasitism \\
\hline CONTROL & 4.13 & & 6.66 & & 9.00 & & \\
\hline C.D. & 0.20 & & 0.19 & & 0.176 & & \\
\hline C.V. & 4.31 & & 4.49 & & 4.554 & & \\
\hline
\end{tabular}

harzianum and $T$. virens, respectively. It was concluded that a novel strain of $T$. harzianum (SVPUTh91) was a good candidate for biological control compare to other Trichoderma spp. due to the different modes of action the fungus employs in inhibiting the growth of other fungi, and indicates this isolate of T. harzianum can be used for production and development of $T$. harzianum based biocontrol formulation to control Fusarium wilt diseases of plants and serve as a model for environment friendly biocontrol agent.

\section{ACKNOWLEDGEMENTS}

Authors are thankful to the Department of Science and Technology, Govt. of India, New Delhi, for providing financial support under project no. SR/SO/PS-21/10 at Plant Health Clinic, Department of Plant Pathology, S. V. Patel University of Agriculture and Technology, Meerut, India.

\section{REFERENCES}

Agrios, G.N. (2005). Significance of plant disease, In: (Agrios, G.N. ed.), Plant Pathology $5^{\text {th }}$ edition. Academic Press, London, pp. 25-37.
Almassi, F., Ghisalberti, E.L. and Narbey, M.J. (1991). New antibiotics from stran of T. harzianum. J. Nat. Product, 54: 396-402

Anees, M., Tronsmo, A., Edel-Hermann, V., Gordon, H.L., Héraud, C. and Steinberg, C. (2010). Characterization of field isolates of Trichoderma antagonistic against Rhizoctonia solani. Fungal Biol., 114: 691-701

Askew, D.J. and Laing, M.D. (1994). The in vitro screening of 118 Trichoderma isolates for antagonism to Rhizoctonia solani and an evaluation of different environmental sites of Trichoderma as sources of aggressive strains. Plant Soil, 159: 277-81

Avis, T.J., Hamelin, R.C. and Belanger, R. (2001). Approaches to molecular characterization of fungal biocontrol agents: some case studies. Can. J. Plant Pathol., 23: 812.

Biswas, K.K. and Das, N.D. (1999). Biological control of pigeon pea wilt caused by Fusarium udum with Trichoderma spp. Ann. Plant Protec. Sci., 7(1): 46-50

Brewer, D., Mason, F.G. and Taylor, A. (1987). The production of alamethicins by Trichoderma spp. Can. J. Microbiol., 33: 619-625.

Brimner, T.A. and Boland, G.J. (2003). A review of the non-target effects of fungi used to biologically control plant diseases. Agri. Ecosyst. Environ., 100: 3-16.

Cal, A., Larena, I., Sabuquillo, P. and Melgarejo, P. (2004). 
Biological control of tomato wilts. Recent Research Development in Crop Sci., 1: 97-115

Chaube, H.S., Mishra, D.S., Varshney, S., and Singh, U.S. (2002). Biological control of plant pathogens by fungal antagonistic: Historical background, present status and future prospects. Annu. Rev. Plant Pathol., 2: 1-42.

Chet, I. (1987). Trichoderma applications, mode of action and potential as a biocontrol agent of soil-borne plant pathogenic fungi. In: (Chet, I. ed.) Innovative approaches to plant disease control. John Wiley \& Sons, New York, pp. 137-160.

Chet, I. and Baker, R. (1980). Induction of suppressiveness to Rhizoctonia solani in soil. Phytopathol., 70: 994-998

Chet, I. and Baker, R. (1981). Isolation and biocontrol potential of Trichoderma hamatum from soil naturally suppressive to Rhizoctonia solani. Phytopathol., 71: 286 -290 .

Chet, I. and Inbar, J. (1994). Biological control of fungal pathogen. Appl. Biochem. Biotechnol., 48:37-43

Choudary, K.A., Reddy, K.R.N. and Reddy, M.S. (2007). Antifungal activity and genetic variability of Trichoderma harzianum isolates. J. Mycol. Plant Pathol., 37(2): 1-6

Claydon, N., Allan, M., Hanso, J.R. and Avent, A.G. (1987). Antifungal alkyl pyrones of Trichoderma harzianum. Trans. Br. Mycol. Soc., 88: 503-513

Dennis, C. and Webster, J. (1971). Antagonism properties of species groups of Trichoderma, II production of volatile antibiotics Trans. Br. Mycol. Soc., 57: 41-48

Dubey, S.C. and Suresh, M. (2006). Randomly Amplified Polymeric DNA Markers for Trichoderma species and Antagonism against Fusarium oxysporum f. sp. ciceris causing Chickpea Wilt. Journal Phytopathol., 154: 663669.

Elad, Y. (2000). Biological control foliar pathogens by means of Trichoderma harzianum and potential modes of action. Crop Protect., 19: 709-714.

Elad, Y., David, D. R., Levi, T., Kapat, A., Krishner, B., Guvrin, E., and Levine, A. (1998b). Trichoderma harzianum, T-39 mechanisms of biocontrol of foliar pathogens. In: (Lyr, H., Russell, P.E., Dehne, H.W. and Sisler, H.D. eds.) Modern fungicides and antifungal compounds II. Andover, Hampshire, UK: Intercept. 459 $-467$.

Elad, Y., Krishner, B., Nitzani, Y., and Sztejnberg, A. (1998a). Management of powdery mildews and gray mold of cucumber by Trichoderma harzianum T39 and Ampelomyces quisqualis AQ10. Biol. Control, 43: 241251.

Gams, W. and Bissett, J. (2002). Morphological and identification of Trichoderma. In: Kubicek, C.P. and Harman, G.E. (eds.). Trochoderma and Gliocladium: Basic biology, taxonomy and genetics. Taylor \& Francis Ltd, London, UK, pp. 3-31.

Haran, S., Schickler, H. and Chet, I. (1996). Molecular mechanism of lytic enzymes involved in the biocontrol activity of T. harzianum. Microbiol. 142: 2321-2331

Harman, G.E., Howell, C.R., Viterbo, A., Chet, I., and Lorito, I.M. (2004). Trichoderma species-Opportunistic, avirulent plant symbionts. Nature Rev., 2: 43-56

Henis, Y. (1984). Biological control. In: (Klug, M. J. and Reddy, C.A. eds.) Current perspectives in microbial ecology. American Society of Microbiology, Washington, pp. 353-361.

Inbar, J., Abransky, D. and Cohen, D. (1994). Plant growth enhancement and disease control by Trichoderma harzianum in vegetable seedlings grown under commercial conditions. Eur. J. Plant Pathol., 100: 337-346.

Joshi, B.B., Bhatt, R.P. and Bahukhandi, D. (2010). Antagonistic and Plant growth activity of Trichoderma isolates of Western Himalaya. J. Environ. Biol., 6: 921-928

Kay, S.J. and Stewart, A. (1994). Evaluation of fungal antagonists for control of onion white rot in soil box trials. Plant Pathol., 43: 371-77.

Kucuk, C. and Kivanc, M. (2003). Isolation of Trichoderma spp. and determination of their antifungal, biochemical and physiological features. Turk. J. Biol., 27: 247-253

Lynch, J.M. (1990). Fungi as antagonists. In: New directions in biological control: Alternatives for suppressing agricultural pests and diseases, Liss, New York, 243-253.

Metcalf, D.D. and Wilson, C.C. (2001). The process of antagonism of Sclerothium cepivorum in white rot affected onion roots by Trichoderma koningii. Plant Pathol., 50: 249-257

NHB Database (2014). Ministry of Agriculture, Government of India (www.nhb.gov.in)

Ojha, S. and Chatterjee, N.C. (2011). Mycoparasitism of Trichoderma spp. in biocontrol of fusarial wilt of tomato. Archive Phytopathol. Plant Protec., 44(8): 771782

Prasad, L., Sagar, S., Chaudhary, S., Kumar, N. and Tomar, A. (2012). Determination of biodiversity using ITSPCR-CAPS markers for Trichoderma sp. from rhizospheric soil of different location in India. Vegetos, 25(2): 336-341.

Prasad, L., Singh, R., Mishra, P. and Rana, N.S. (2010). Biomanurial and biological efficacy of Trichoderma harzianum on red rot disease of sugarcane. Environment and Ecology 28(4): 2229-2231

Ramezani, H. (2008). Biological control of root-rot of eggplant caused by Macrophomina phaseolina. American Eurasian J. Agri. Envir. Sci., 4(2): 218-220

Ramezani, H. (2010). Antagonistic effects of Trichoderma spp. against Fusarium oxysporum f. sp. lycopersici causal agent of tomato wilt. Plant Protec. Journal, 2(1): $167-173$

Rifai, M.A. (1969). A revision of the genus Trichoderma. Mycol. Pap., 116: 1-56.

Samuels, G.J., Chaverri, P., Farr, D.F. and McCray, E.B. (2002). Trichoderma Online. Systematic Mycology and Microbiology Laboratory, ARS, USDA; Retrieved 28, August 2015 from http://nt.ars-grin.gov/ taxadescriptions/keys/TrichodermaIndex.cfm

Sharma, K.K. and Singh, U.S. (2014). Cultural and morphological characterization of rhizospheric isolates of fungal antagonist Trichoderma. J. Appl. \& Nat. Sci. 6(2): 451456.

Siameto, E.N., Okoth, S., Amugune, N.O. and Chege, N.C. (2011). Molecular characterization and identification of biocontrol isolates of Trichoderma harzianum from EMBU district, Kenia. Tropic. Subtropic. Agroecosyst., 13: $81-90$

Sivan, A. and Chet, I. (1993). Integrated control of media on growth and interactions between a range of soilborne glasshouse pathogens and antagonistic fungi. Phytopathol., 10: 127-142

Srinon, W., Chuncheen, K., Jirattiwarutkul, K., Soytong, K. and Kanokmedhakul, S. (2006). Efficacies of antagonistic fungi against Fusarium wilt disease of cucumber and tomato and the assay of its enzyme activity. J. Agri. Technol., 2(2): 191-201 
Sundaramoorthy, S. and Balabaskar, P. (2013). Biocontrol efficacy of Trichoderma spp. against wilt of tomato caused by Fusarium oxysporum f. sp. lycopersici. J. Appl. Biol. \& Biotech., 3(1): 36-40

Tjamos, E.C., Papavizas, G.C. and Cook, R.J. (1992). Biological control of plant diseases: Progress and challenges for the future. Plenum Press, New York.

van Loon, L.C., Bakker, P.A. and Pieterse, C.M. (1998). Systemic resistance induced by rhizosphere bacteria. Annu. Rev. Phytopathol., 36: 453-488

Weller, D.M. (1988). Biological control of soil borne plant pathogens in the rhizosphere with bacteria. Annu. Rev. Phytopathol., 26: 379-469

Whipps, J.M., McQquilken and Budge, S.P. (1993). Use of fungal antagonists for biocontrol of damping-off and Sclerotinia disease. Pestic. Sci., 37: 309-313

White, T.J., Bruns, T., Lee, S. and Taylor, J. (1990). Amplification and direct sequencing of fungal ribosomal RNA genes for phylogenetics. In: (Innis, M.A. et al., eds.) PCR protocol: A guide to methods and applications. Academic Press, San Diego, pp. 315-322. 